\title{
Clinical features, diagnosis, and treatment of traumatic pulmonary pseudocysts
}

\author{
Seray Hazer, M.D., ${ }^{1}$ Umut Perçem Orhan Söylemez, M.D. ${ }^{2}$
}

${ }^{1}$ Department of Thoracic Surgery, Ataturk Chest Diseases and Thoracic Surgery Training and Research Hospital, Ankara-Turkey ${ }^{2}$ Department of Radiology, Bingol State Hospital, Bingol-Turkey

\begin{abstract}
BACKGROUND: Traumatic pulmonary pseudocysts (TPP) are rare complications of blunt chest trauma. The aim of this study is to increase the understanding of this rare entity with imaging and clinical parameters for preventing complications and determining the correct treatment approach by observing 15 cases.

METHODS: We retrospectively reviewed the medical data and thoracic computed tomography scans of 185 patients who underwent examinations in our department after chest trauma between July 2014 and December 2015.

RESULTS: Fifteen patients had TPPs, and their clinical features and imaging findings were evaluated. Their average age was 26.33 (range, 1-89) years. The cause of TPP was traffic accident in 13 patients and falling from a height in two. Tube thoracostomy was required in five patients. None of the patients required thoracotomy, and $66 \%$ of them recovered without any complications. Five patients died because of serious concomitant injuries.
\end{abstract}

CONCLUSION: Sudden shearing force across the pulmonary parenchyma results in an area of pulmonary contusion and airtransfer from the airway to the contused area, which in turn leads to pneumatocele formation. Conservative treatment is recommended for these patients, but complications can occur because of cyst rupture. Patients should be closely monitored and be made aware of the risk of life-threatening complications.

Keywords: Blunt chest trauma; computed tomography; pneumatocele; traumatic pulmonary pseudocyst.

\section{INTRODUCTION}

Lung parenchymal injury caused by blunt chest trauma is frequently accompanied by pulmonary contusion and intrapulmonary hemorrhage; however, the occurrence of traumatic pulmonary pseudocyst (TPP) is uncommon. ${ }^{[1]}$ The compliance of the osteochondral thoracic cage can allow the transmission of compressive force to the lung parenchyma in young individuals. Small lacerations occur with rapid compression and decompression of the parenchyma, and the retraction of the surrounding elastic lung tissue results in the formation of small cavities that fill with air or fluid. ${ }^{[2]}$ TPP occurs in $2.9 \%$ of pulmonary parenchymal injuries and $0.34 \%$ of all chest traumas. ${ }^{[3]}$ The appearance of TPP on chest X-ray depends on the size and location of the lesion, severity of pulmonary con- tusion, and position of the patient (recumbent or upright). Thoracic computed tomography (CT) provides detection and evaluation of TPP with $100 \%$ sensitivity. ${ }^{[1]}$

This study aimed to elucidate concomitant injuries, most common localization, treatment strategies, and prognosis of TPP and define radiological appearance of TPP on CT. Radiologic and clinical features of 15 patients admitted to our emergency department with TPP after blunt chest trauma were retrospectively evaluated.

\section{MATERIALS AND METHODS}

We reviewed the data of 185 patients who underwent thoracic $\mathrm{CT}$ examinations in our department after chest trauma

Cite this article as: Hazer S, Söylemez UPO. Clinical features, diagnosis, and treatment of traumatic pulmonary pseudocysts.

Ulus Travma Acil Cerrahi Derg 2018;24:49-55

Address for correspondence: Seray Hazer, M.D.

Atatürk Göğüs Hastalıkları ve Göğüs Cerrahisi Eğitim ve Araştırma Hastanesi, Göğüs Cerrahisi Kliniği, Ankara, Turkey.

Tel: +90 312 - 5677000 E-mail: drserayhazer@gmail.com

Ulus Travma Acil Cerrahi Derg 2018;24(I):49-55 DOI: 10.5505/tjtes.2017.56023 Submitted: 18.06.2016 Accepted: 15.05.2017

Copyright 2018 Turkish Association of Trauma and Emergency Surgery 
between July 2014 and December 20I5. TPPs were detected in 15 patients (8.1\%). Patients with pseudocysts that developed after penetrating trauma were excluded from our study. The CT scan field extended from the level of the thoracic inlet down to the posterior costophrenic sulci. The scanning parameters were $100 \mathrm{mAs}, 120 \mathrm{kV}, 3-\mathrm{mm}$ slice thickness, and $0.863 \mathrm{I}$ pitch. All images were viewed in mediastinal, pulmonary, and bone window settings and evaluated by a radiologist. The number, shape (circular, oval, and lobulated), location (segment), air-fluid levels within the lesions (intracavitary fluid), and other pulmonary and extrapulmonary injuries were recorded (Table I, 2). Size measurements were obtained for craniocaudal and transverse diameters (Fig. I).

Cavitary lesions that surrounded by parenchymal contusion were determined in different shapes (circular, oval, and lobulated ). The other reasons of cavitary lesions were excluded, and the lesions that rapidly changed pattern or resolved in the follow-up examinations without a specific treatment were diagnosed as TPP. The indication for tube insertion was determined by the presence of $\geq 10 \%$ pneumothorax or hemothorax in a hemithorax or presence of symptoms of cardiac or pulmonary insufficiency. Patients with serious abdominal injuries underwent abdominal exploration. When large air leaks, mediastinal emphysema, or lobular atelectasis were detected, bronchoscopy was performed. Patients were admitted to the intensive care unit if life-threatening complications occurred. Chest X-rays were obtained daily during the hospitalization period, and patients were followed up with first-week, first-month, and third-month control chest X-rays.

The resolution time of pseudocysts was analyzed using the Kaplan-Meier curve, and deceased patients were excluded for this analyze. The log-rank test was used to compare recovery curves. The effects of size of TPP and intracavitary fluid on resolution time were analyzed using the Cox regression method.

\section{RESULTS}

TPP was detected in 15 patients ( 13 males, 2 females) after blunt chest trauma. Their average age was 26.33 (range, I-89) years. The cause of TPP was traffic accidents in 13

Table I. Extrathoracic injuries in patients with traumatic pulmonary pseudocyst

\begin{tabular}{|c|c|c|c|}
\hline Patient & Brain injury & Abdominal injury & Bone fracture \\
\hline I & Subarachnoid hemorrhage & - & $\begin{array}{l}\text { Lumbar vertebrae, scapula, and } \\
\text { pelvic bone fractures }\end{array}$ \\
\hline 2 & - & Spleen laceration & Pelvic bone fracture \\
\hline 3 & Subarachnoid hemorrhage & Retroperitoneal hematoma & $\begin{array}{l}\text { Humerus, thoracic, and lumbar } \\
\text { vertebrae fractures }\end{array}$ \\
\hline 4 & - & - & Thoracal vertebrae fracture \\
\hline 5 & $\begin{array}{l}\text { Cerebral contusion, and subdural } \\
\text { hemorrhage }\end{array}$ & - & $\begin{array}{l}\text { Metacarpal, cervical, and } \\
\text { thoracal } \\
\text { vertebrae fractures }\end{array}$ \\
\hline 6 & $\begin{array}{l}\text { Subarachnoid hemorrhage, and } \\
\text { cerebral contusion }\end{array}$ & Spleen and pancreatic contusions & Clavicular fracture \\
\hline 7 & & & Femoral diaphysis fracture \\
\hline 8 & - & - & - \\
\hline 9 & - & $\begin{array}{l}\text { Liver, kidney, and spleen laceration, and } \\
\text { renal and retroperitoneal hematomas }\end{array}$ & - \\
\hline 10 & Scalp hematoma & Adrenal hematoma & Scapula and pelvic bone fractures \\
\hline II & $\begin{array}{l}\text { Subarachnoid and intraventricular } \\
\text { hemorrhages, calvarial, and maxillofacial } \\
\text { fractures, and pneumocephalus }\end{array}$ & - & - \\
\hline 12 & $\begin{array}{l}\text { Subarachnoid hemorrhage, and } \\
\text { calvarial fractures }\end{array}$ & Retroperitoneal hematoma & - \\
\hline 13 & - & - & Lumbar vertebrae fracture \\
\hline 14 & - & Liver contusion, and right adrenal hemorrhage & Lumbar vertebrae fracture \\
\hline 15 & - & - & Scapula fracture \\
\hline
\end{tabular}


Table 2. Characteristics of traumatic pulmonary pseudocyst

\begin{tabular}{|c|c|c|c|c|}
\hline Patient & Number of cysts & Size of the biggest cyst $(\mathrm{mm})$ & Location & Shape \\
\hline I & II & $1|x| 2$ & Left lower lobe & Circular \\
\hline 2 & 5 & $7 \times 8$ & Left upper lobe (4), Right lower lobe (I) & Circular \\
\hline 3 & 2 & $31 \times 32$ & Right lower lobe & Lobulated \\
\hline 4 & 1 & $24 \times 36$ & Right lower lobe & Oval \\
\hline 5 & 9 & $9 \times 15$ & Left upper lobe (8), Right upper lobe (I) & Circular and oval \\
\hline 6 & 2 & $|9 \times 2|$ & Left upper lobe & Circular \\
\hline 7 & 2 & $|0 x| \mid$ & Left upper lobe & Circular \\
\hline 8 & 6 & $21 \times 23$ & Right upper lobe (2), Left lower lobe (4) & Circular and lobulated \\
\hline 9 & 8 & $16 \times 21$ & Right upper lobe (2), Right lower lobe (6) & Oval \\
\hline 10 & 2 & $9 \times 15$ & Left lower lobe & Oval \\
\hline II & 7 & $14 x \mid 8$ & Right upper lobe (3), Right lower lobe (4) & Oval and lobulated \\
\hline 12 & 4 & $|7 x| 8$ & Right upper lobe & Circular \\
\hline 13 & 2 & $6 \times 12$ & Left upper lobe & Oval \\
\hline 14 & 4 & $13 \times 27$ & Right upper lobe & Oval and lobulated \\
\hline 15 & 1 & $16 \times 18$ & Right upper lobe & Lobulated \\
\hline
\end{tabular}

patients and falling from a height in two. The most common clinical symptoms were chest pain, dyspnea, and cough. Rib fractures were identified in II patients (Fig. 2), intracavitary fluid in eight (Fig. 3), hemopneumothorax in seven, and pneumothorax in four (Fig. 4). A chest tube was inserted in five patients, and none required thoracotomy (Table 3). TPPs were located in the left upper lobe in 5 patients, right upper lobe in six, and left lower lobe in three. Intracavitary fluid was observed in eight patients. The pseudocysts were classified as circular in seven patients, lobulated in five, and oval in seven. Pseudocysts of both circular, oval and lobulated shapes were observed in four patients (Table 2). The size of the biggest

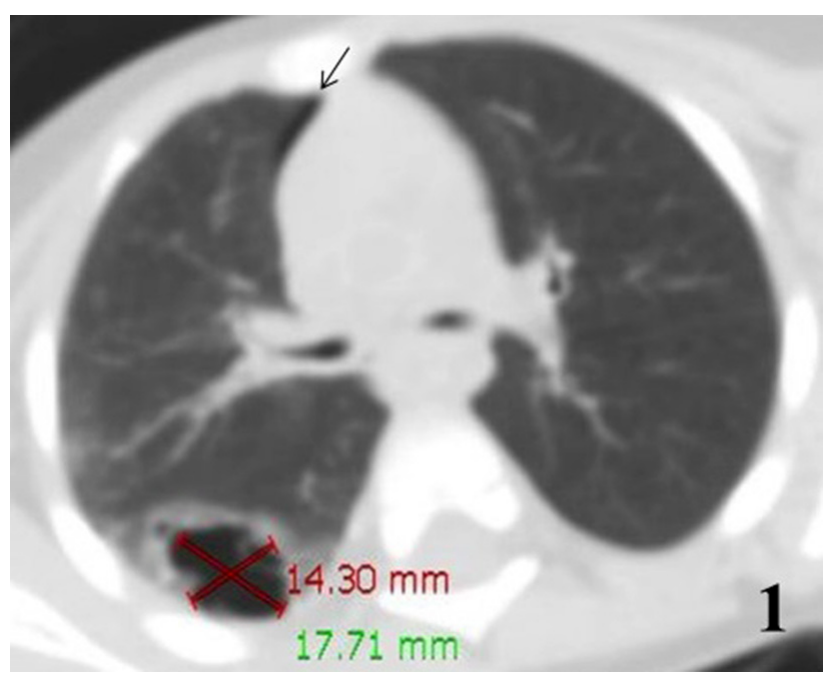

Figure 1. The cystic cavitary circular-shaped lesion in the right upper lobe posterior segment. Size measurement is shown (14x $17.7 \mathrm{~mm}$ ). There is a hyperdense rim in the cyst's periphery due to contusion. Thin pneumothoraxis seen anteriorly (black arrow).

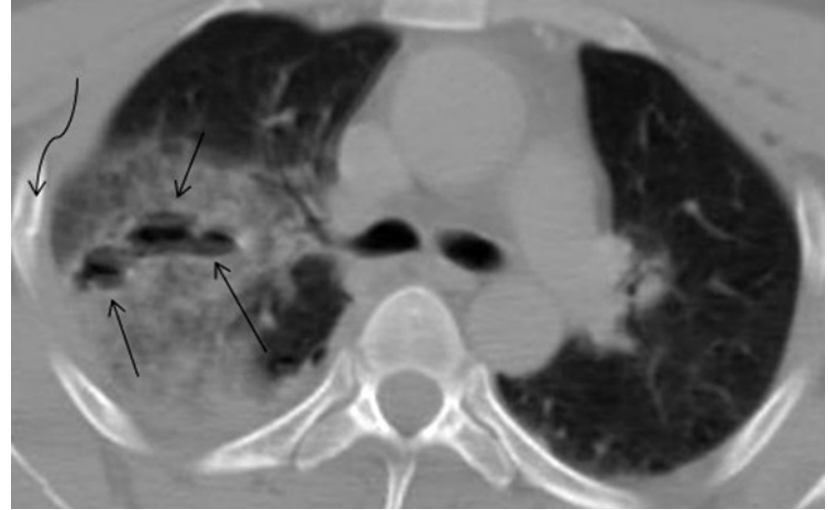

Figure 2. Three oval-shaped cystic lesions seen in the right upper lobe (arrows). Air-fluid level can be seen in the cysts consistent with intracavitary fluid. Patchy hyperdense contusion areas surraund the cysts. Rib fracture can also be seen (curved arrow).

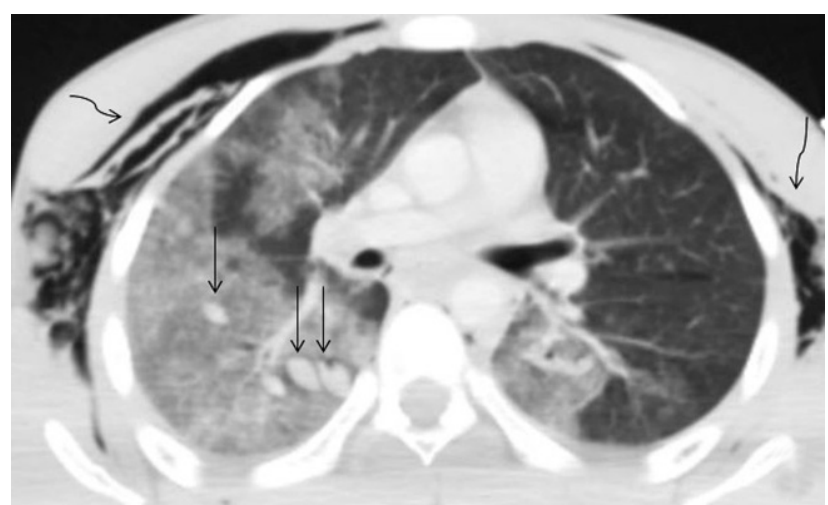

Figure 3. Oval-shaped hyperdense lesions seen in the right upper lobe posterior segment. The cysts are filled with blood (arrows). Subcutaneous emphysema is seen (curved arrows). Contusion areas can be seen in both lung parenchymas. 


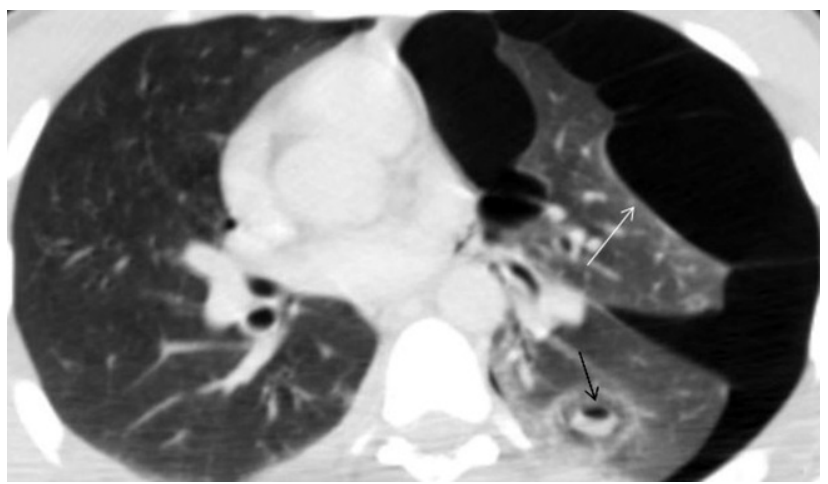

Figure 4. Oval-shaped pseudocyst in the left lower lobe (black arrow). Intracavitary hemorrhage is seen in the cyst as air-fluid level. Pneumothorax was seen on the left side (white arrow).

cyst measured was $36 \mathrm{~mm}$ and that of the smallest cyst was $6 \mathrm{~mm}$ (Table 2).

Radiological and clinical findings revealed other organ injuries in addition to lung injuries in 13 patients. Other radiological findings included bone fractures [scapula, clavicle, femoral diaphysis, pelvis, calvarium, maxillofacial, metacarpal, humerus, and vertebrae (cervical, thoracic and lumbar)]; lacerations of the liver, spleen, and kidneys; retroperitoneal, calvarial, adrenal, and subdural hematomas; subarachnoid and intraventricular hemorrhage; pneumocephalus; splenic and liver contusions; and perisplenic fluid (Table I). Five patients died because of severe concomitant brain and abdominal injuries. Ten patients recovered without any complications, and their pseudocysts resolved completely. An 18-year-old male patient required mechanical ventilation because of cranial injury. Pneumonia occurred during follow-up in the intensive care
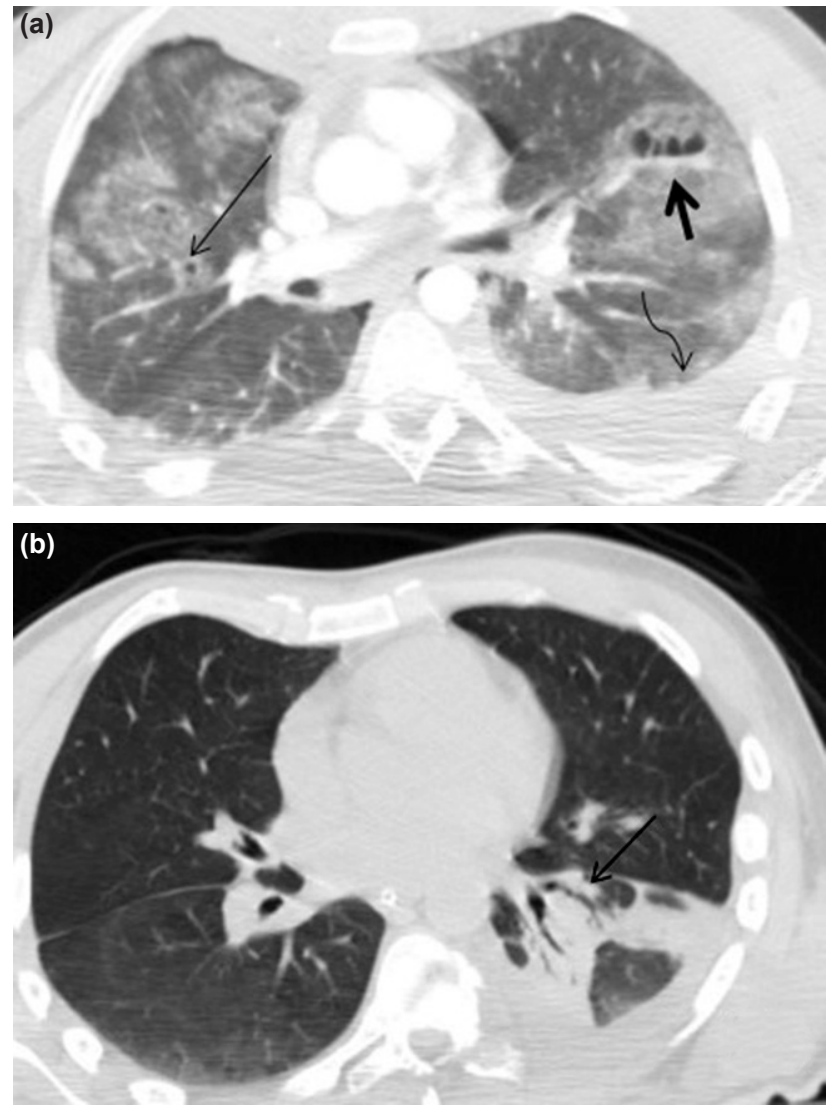

Figure 5. (a) Multiple circular-shaped pseudocysts in the left upper lobe anterior segment (thick black arrow). Smaller pseudocysts can also be seen in the left lung (thin black arrow). Hemothorax is seen (curved arrow). (b) 7 days after trauma consolidation, air bronchograms occurred in the patient (arrow). The clinical symptoms were consistent with pneumonia.

Table 3. Characteristics such as patient age, gender, etiology of trauma, thoracic posttraumatic findings, and chest tube insertion

\begin{tabular}{|c|c|c|c|c|c|c|c|c|c|}
\hline Patient & Age & Gender & Trauma & Pneumothorax & Hemothorax & $\begin{array}{l}\text { Sternum } \\
\text { fracture }\end{array}$ & $\begin{array}{c}\text { Rib } \\
\text { fracture }\end{array}$ & $\begin{array}{c}\text { Intracavitary } \\
\text { fluid }\end{array}$ & $\begin{array}{l}\text { Chest tube } \\
\text { insertion }\end{array}$ \\
\hline I & 23 & Female & Fall from height & + & + & - & + & + & + \\
\hline 2 & 6 & Male & Traffic accident & + & - & - & + & - & - \\
\hline 3 & 28 & Male & Traffic accident & - & + & - & + & + & - \\
\hline 4 & 30 & Male & Traffic accident & - & - & + & - & - & - \\
\hline 5 & 22 & Male & Traffic accident & + & + & + & + & + & + \\
\hline 6 & 23 & Male & Traffic accident & + & - & - & - & - & + \\
\hline 7 & 25 & Male & Traffic accident & - & - & - & + & - & - \\
\hline 8 & 21 & Male & Traffic accident & + & - & - & + & + & - \\
\hline 9 & 16 & Male & Traffic accident & + & + & - & + & + & + \\
\hline 10 & 18 & Male & Traffic accident & + & + & - & + & + & - \\
\hline II & 1 & Female & Fall from height & + & - & - & - & - & - \\
\hline 12 & 89 & Male & Traffic accident & + & + & - & + & + & + \\
\hline 13 & 26 & Male & Traffic accident & - & - & - & - & - & - \\
\hline 14 & 41 & Male & Traffic accident & + & + & - & + & + & - \\
\hline 15 & 26 & Male & Traffic accident & + & + & + & + & - & - \\
\hline
\end{tabular}




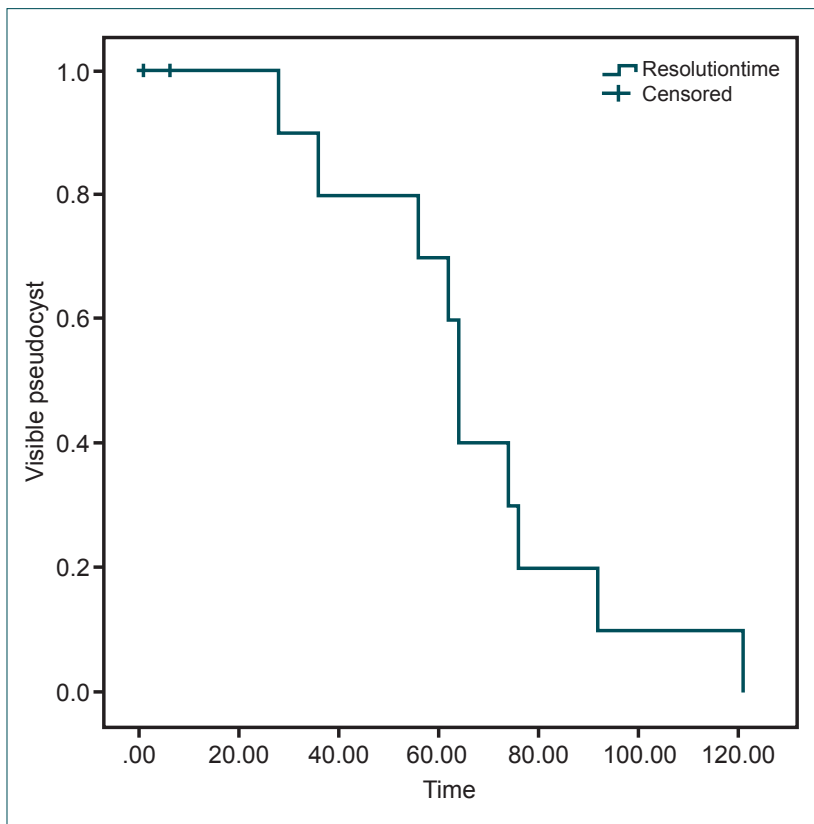

Figure 6. Table shows the resolution time of the pseudocysts. The mean resolution time was 45.53 days, and the median resolution time was 56.0 days. (Visible Pseudocysts = percentage of patients, resolution time $=$ days).

unit and antibiotic treatment was initiated (Fig. 5).

The mean resolution time was 45.53 days (24.3-66.8 days, $95 \%$ confidence interval for mean), and the median resolution time was 56.0 days (Fig. 6). There was no correlation between cyst size and resolution time. Correlation between intracavitary fluid and resolution time was determined. Pseudocysts without fluid were resolved earlier (median, 56 days) than pseudocysts with fluid (median, 74 days; $p=0.04$ ).

\section{DISCUSSION}

In our study, TPPs were detected in $8.1 \%$ of patients with blunt chest traumas, and this rate was higher than that reported in the literature. Sudden shearing force across the pulmonary parenchyma leads to an area of pulmonary contusion and airtransfer from the airway to the contused area, which in turn results in pneumatocele formation. TPP is defined as an air-filled cavitary lesion without epithelial lining developing in the pulmonary parenchyma after blunt chest trauma. TPPs result from pulmonary parenchymal laceration as the initial event followed by normal elastic recoil of the surrounding lung with air trapping in the remaining cavity. ${ }^{[4]}$ The moreelastic chest walls of young patients permit greater transmission of kinetic energy to the lung parenchyma; therefore, TPP is more common in pediatric and young adult patients. Because of rapid compression and decompression, lacerations occur and the cavities fill with air or blood. ${ }^{[5]}$

TPP can develop after either blunt, penetrating, or barotrauma, and there is no significant difference between the proportions of patients with TPP with these trauma types. Particularly in infants, single or multiple well-demarcated cystic air collections can develop as a complication of mechanical ventilation. [6] Some studies have explained that the reason for the higher frequency of TPPs in younger age groups is that the chest walls of younger patients are more compliant and permit greater transmission of impact to the lungs. ${ }^{[6]}$ In our series, most of the patients ( $86 \%$ ) were in the younger age group ( $\leq 30$ years), but the other two cases were $4 \mathrm{I}$ and 89 years old.

TPPs can be detected on chest X-rays as thin-walled cavities filled with air or with air-fluid levels if hemorrhage occurs. They are mostly seen on chest X-rays as circular, oval, or lobulated cavitary lesions immediately adjacent to or within an area of contusion. The most characteristic feature of TPPs is that they change in size, shape, and nature within days. All patients had lung contusions, and in one patient, a control CT examination showed intracystic fluid (Fig. 7). TPPs were located in the left upper lobe (33\%), right upper lobe $(33 \%)$, left lower lobe (13\%), and in both right upper and left lower lobes (7\%). Rib fractures (73\%), intracavitary fluid (53\%), hemopneumothorax (46\%), and pneumothorax (25\%) were detected on the first radiological examination.

Thoracic CT is a sensitive method for the early detection of TPP and allows differential diagnosis of the lesion. A diagnosis of TPP can be confidently made in patients who develop the
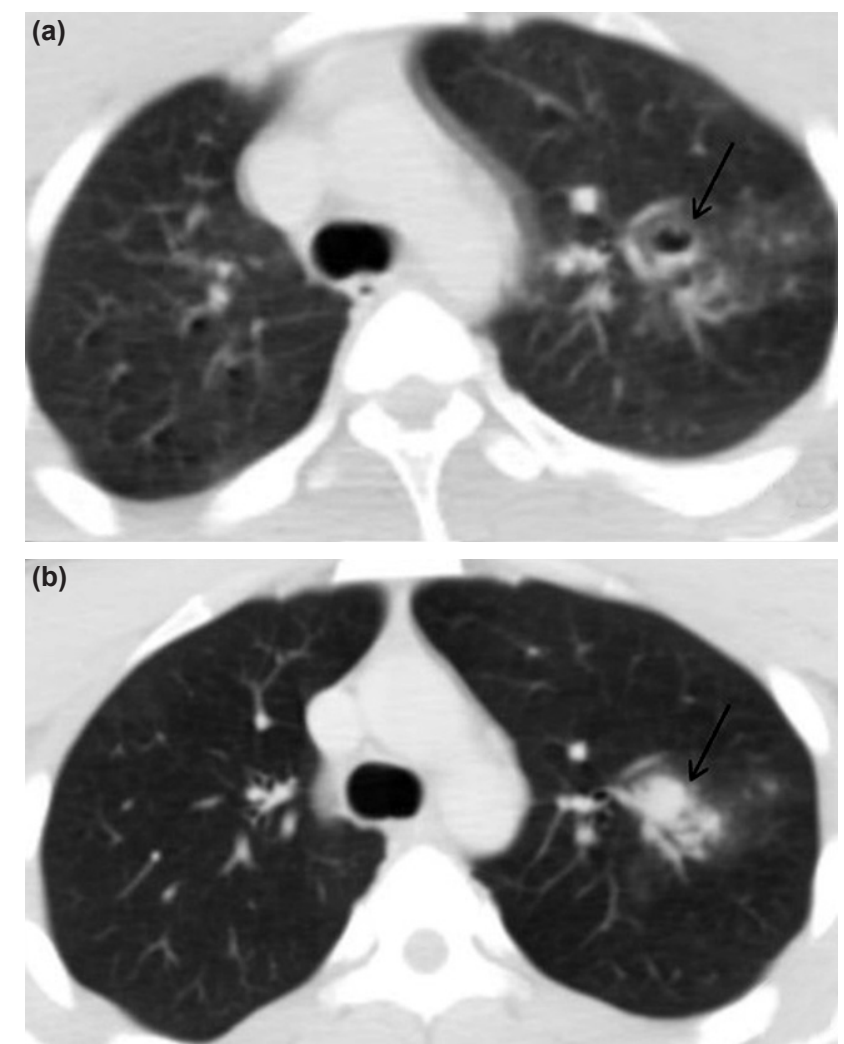

Figure 7. (a) Oval-shaped pseudocyst in the left upper lobe (arrow). (b) In the third day of trauma, control CT showed that the cyst filled with hemorrhage and seem as hyperdense parenchymal lesion (arrow). 
characteristic cystic lesion shortly after chest trauma occurs. TPP is not always apparent in the first $48 \mathrm{~h}$ on chest $\mathrm{X}$-rays. Chest X-ray on the day of injury has a diagnostic yield of $33 \%-50 \%$ because of the lesions being too small and/or obscured by pulmonary contusion opacities. ${ }^{[6]}$ In most cases, TPP is detectable on chest X-ray after a few days because by this time, the lung contusions have resolved to some degree or the TPPs have developed fully. Routine use of CT in cases of chest trauma will help in identifying lesions that are undetectable on chest X-rays. In addition, other cavitary pulmonary lesions, such as lung abscess, cavitary tuberculosis, mycosis, cancer, hematoma, bronchial cyst, and pulmonary sequestration, can easily be ruled out. ${ }^{[7]}$ In cases of suspicion of bronchial or tracheal injury after blunt trauma, flexible bronchoscopy should be performed.

The most frequent clinical symptoms of TPP are tachypnea, cough, pain, and hemoptysis occurring within 12-36 h after trauma. ${ }^{[8]}$ In our study, $60 \%$ of patients had chest pain, $40 \%$ had dyspnea, and $30 \%$ had cough. The I-year-old female who was admitted because of a fall from a height was unconscious. Chest tube was inserted in five patients. The indication for tube insertion was determined by the presence of $\geq 10 \%$ pneumothorax or hemothorax in a hemithorax. There was no enlargement of pseudocyst or progression of intracavitary fluid; therefore, none of patients required surgery due to pseudocyst.

None of the patients required thoracic exploration. Conservative treatment is considered to be a better choice for patients with TPP and includes follow-up; however, the occasional use of antibiotics to guard against secondary infection is controversial. ${ }^{[9]}$ Although antibiotic prophylaxis is not routinely recommended, early antibiotic treatment is necessary if there is persistent fever, leukocytosis, radiographic features, intubation, mechanical ventilation, or other signs of an increased risk of infection. ${ }^{[l]}$ We used prophylactic antibiotics for all patients, nevertheless pneumonia occurred in one patient who was intubated in the intensive care unit. Complications such as cardiopulmonary compression caused by progressive enlargement of a pseudocyst, superinfection, pneumothorax, hemothorax, and hemoptysis due to TPP rupture may occur. Clinical deterioration has been shown to respond very successfully to radiographically guided percutaneous drainage. If drainage and coagulation are successfully restored and bleeding is controlled with minimally invasive approaches, surgical procedures may be prevented. Repeated bronchoscopies with airway toilet and kinetic therapy/postural drainage are alternative treatment initiatives during the early phase. ${ }^{[10]}$ Kinetic therapy and postural drainage, even used prophylactically in multiple trauma patients whose injuries and pattern predispose to acute respiratory distress syndrome, have been shown to improve oxygenation in patients with impaired pulmonary function. ${ }^{[11,12]}$ Double-lumen endotracheal intubation and embolization may be considered if bleeding originates from one lobe only. Surgery is rarely needed and is typically reserved for cases in which percutaneous drainage is not feasible or not successful. Surgical management has traditionally taken the form of either tube insertion or thoracotomy with lobectomy. [9] In our study, only 33\% of patients required tube insertion and none underwent thoracotomy.

Chon's study showed significant differences in resolution times between cysts $<2 \mathrm{~cm}$ and those $>2 \mathrm{~cm}$, as well as between blood-filled pseudocysts and uncomplicated pseudocysts. The complete resolution time ranged between 9 and 305 days. ${ }^{[10]}$ Some studies determined that TPP complications developed between I and 9 days (especially within 5 days) after trauma; therefore, close follow-up is necessary for the first 5 days for possible complications. ${ }^{[6]}$ In our series, pneumothorax occurred in two patients on the second day. There was no correlation between cyst size and resolution time. Correlation between intracavitary fluid and resolution time was determined. Pseudocysts without fluid were resolved earlier (median, 56 days) than pseudocysts with fluid (median, 74 days). Number of cysts and presence of intracavitary hemorrhage did not affect the complication rates.

After blunt chest trauma, TPP can occur rarely and usually resolves within I-4 (average, I.8) months. ${ }^{[7]}$ Atelectatic areas or fibrous scars can persist when the pseudocyst doesnot entirely resolve. Thoracic CT is superior to chest X-ray for identifying cysts within contusions. The correct diagnosis of TPP with radiological imaging can help the physician prevent complications and avoid unnecessary interventions. Typically, the prognosis is good for TPP and its unusual complications. TPPs are seen after high-energy trauma, so the radiologist and physician must be aware of other systemic injuries. Chest $X$-ray is usually sufficient for follow-up in most patients with TPP, but in complicated cases, CT is the best choice for complications such as hemorrhage, infection, abscess formation, and rupture.

In our patients, most of the lesions were located in a subpleural parenchyma near the chest wall where rib fractured and swelling of soft tissue or subcutaneous emphysema was observed. In our series, 12 lesions (22.6\%) had an irregular shape, which was different from all TPPs that have a round or oval shape as reported in the literature. Five lesions with irregularly shaped images were confirmed in this study by coronal planar reformation images. The mean size of the lesions in our patients was $1.8 \mathrm{~cm}$, which was smaller than that reported in the literature (average, $2-10 \mathrm{~cm}$ ). All irregular lesions were $>2 \mathrm{~cm}$ in size in our study. The sizes of TPPs with irregular shape (mean, $3.5 \mathrm{~cm}$ ) were significantly larger than those with oval shape (mean, $1.5 \mathrm{~cm}$ ). This could be related to the presence of disrupted interlobular septum in the irregularly shaped lesions.

In conclusion, the incidence of TPPs in our study is higher than that reported in previous studies. CT can accurately demonstrate the characteristics of the lesions and complica- 
tions. Irregularly shaped cavities were significantly larger than those with an oval shape, and air-filled pseudocysts resolved more quickly than those containing fluid. Patients with TPP with pneumothorax, hemothorax, or both can be treated with drainage and/or surgical hemostasis instead of TPP resection. Patients with TPP without these complications may recover without treatment. TPP does not require follow-up $\mathrm{CT}$ scan or intervention in the absence of complications.

Conflict of interest: None declared.

\section{REFERENCES}

1. Zheng Z, Pan Y, Guo F, Pan T, Li J. Traumatic pulmonary pseudocyst: a rare but noteworthy entity. Am Surg 2011;77:1098-100.

2. Tsitouridis I, Tsinoglou K, Tsandiridis C, Papastergiou C, Bintoudi A. Traumatic pulmonary pseudocysts: CT findings. J Thorac Imaging 2007;22:247-51. [CrossRef]

3. Kocer B, Gulbahar G, Gunal N, Dural K, Sakinci U. Traumatic pulmonary pseuodocysts: two case reports. J Med Case Rep 2007;1:112.

4. Melloni G, Cremona G, Ciriaco P, Pansera M, Carretta A, Negri G, et al. Diagnosis and treatment of traumatic pulmonary pseudocysts. J Trauma 2003;54:737-43. [CrossRef]

5. Koç I. Traumatic pulmonary pseudocyst: A case report. J Clin Exp Invest
2014;5:304-6. [CrossRef]

6. Ulutas H, Celik MR, Ozgel M, Soysal O, Kuzucu A. Pulmonary pseudocyst secondary to blunt or penetrating chest trauma: clinical course and diagnostic issues. Eur J Trauma Emerg Surg 2015;41:181-8. [CrossRef]

7. Shin MS, Ho KJ. Computed tomography evaluation of posttraumatic pulmonary pseudocysts. Clin Imaging 1993;17:189-92. [CrossRef]

8. Van Hoorebeke E, Jorens PG, Wojciechowski M, Salgado R, Desager $\mathrm{K}$, Van Schil P, et al. An unusual case of traumatic pneumatocele in a nine-year-old girl: a bronchial tear with clear bronchial laceration. Pediatr Pulmonol 2009;44:826-8. [CrossRef]

9. Jackson CC, Bettolli M, De Carli C, Rubin S, Sweeney B. Thoracoscopic treatment of a neonatal traumatic pneumatocele. J Laparoendosc Adv Surg Tech A 2008;18:170-3. [CrossRef]

10. Chon SH, Lee CB, Kim H, Chung WS, Kim YH. Diagnosis and prognosis of traumatic pulmonary psuedocysts: a review of 12 cases. Eur J Cardiothorac Surg 2006;29:819-23. [CrossRef]

11. Steinhausen E, Bouillon B, Yücel N, Tjardes T, Rixen D, Paffrath T, et al. Nonoperative management of post-traumatic pulmonary pseudocyst after severe thoracic trauma and hemorrhage by coagulation management, kinetic therapy, and control of secondary infection: a case report. J Trauma 2007;63:1391-4. [CrossRef]

12. Staudinger T, Kofler J, Müllner M, Locker GJ, Laczika K, Knapp S, et al. Comparison of prone positioning and continuous rotation of patients with adult respiratory distress syndrome: results of a pilot study. Crit Care Med 2001;29:51-6. [CrossRef]

\section{ORIJINAL ÇALIŞMA - ÖZET}

\section{Travmatik pulmoner psödokistlerde klinik özellikler, tanı ve tedavi yöntemleri}

\section{Dr. Seray Hazer, ${ }^{1}$ Dr. Umut Perçem Orhan Söylemez ${ }^{2}$}

${ }^{1}$ Atatürk Göğüs Hastalıkları ve Göğüs Cerrahisi Eğitim ve Araştırma Hastanesi, Göğüs Cerrahisi Kliniği, Ankara

${ }^{2}$ Bingöl Devlet Hastanesi, Radyoloji Kliniği, Bingöl

AMAÇ: Travmatik pulmoner psödokistler künt göğüs travmalarının nadir komplikasyonlarıdır. Çalışmamızın amacı, bu nadir durumun komplikasyonlarından kaçınmak ve doğru tedavi yaklaşımını tespit etmek üzere 15 olgunun radyolojik ve klinik parametrelerle değerlendirilmesidir.

GEREÇ VE YÖNTEM: Temmuz 20।4-Aralık 2015 tarihleri arasında kliniğimizde toraks travması nedeniyle takip edilen 185 hastanın bilgileri ve radyolojik görüntüleri geriye dönük olarak değerlendirildi.

BULGULAR: Travmatik pulmoner psödokist tespit edilen 15 hastanın klinik özellikleri ve görüntüleme bulguları değerlendirildi. Ortalama yaş 26.33'dü (I-89 yaş). On üç olguda etiyolojide trafik kazası sorumlu iken iki olguda yüksekten düşme sonrası gelişmişti. Beş olguda tüp torakostomi uygulandı. Olguların \%66'sı komplikasyonsuz iyileşti ve hiçbir olguda torakotomi gereksinimi olmadı. Beş olgu, eşlik eden toraks dışı ciddi yaralanmaya bağlı olarak kaybedildi.

TARTIŞMA: Pnömotosel formasyonu akciğer parankiminde meydana gelen ani makaslama gücü etkisiyle parankimde kontüzyon gelişmesi ve kontüzyon alanından ani hava çıkışıyla oluşmaktadır. Bu hastalarda önerilen tedavi yaklaşımı konservatif olmakla birlikte kist rüptürüne bağlı komplikasyonlar gelişebilir. Hastalar yakın takip edilmelidirler ve hayatı tehdit eden komplikasyonlar açısından dikkatli olunmalıdır.

Anahtar sözcükler: Bilgisayarlı tomografi; künt göğüs travması; pnömotosel; travmatik pulmoner psödokist.

Ulus Travma Acil Cerrahi Derg 2018;24(I):49-55 doi: 10.5505/tjtes.2017.56023 